\section{Tryptophan under suspicion}

\section{Washington}

DEBATE over the safety of recombinantDNA technology is heating up again following the publication of a paper in the New England Journal of Medicine that describes a possible link between an outbreak of eosinophilia-myalgia syndrome (EMS), a sometimes fatal blood disorder, and the consumption of a genetically engineered amino acid. Jeremy Rifkin, president of the Foundation on Economic Trends, a Washington-based group that has long opposed the use of recombinantDNA technology, has quickly seized upon the new data and petitioned the US Food and Drug Administration (FDA) to stop the licensing of all new genetically engineered products until a full public inquiry has been carried out.

The product implicated in the EMS outbreak, which affected more than 1,500 Americans and led to 27 deaths, was L-tryptophan, a dietary supplement commonly taken to alleviate insomnia, depression and premenstrual tension. Although six companies manufacture Ltryptophan and import it into the United States, Michael Osterholm of the Minnesota Department of Health and his coworkers report in the New England Journal of Medicine (323, 9 August 1990) that the outbreak of EMS can be linked to batches of L-tryptophan manufactured in early 1989 by Showa Denko, Japan's fourth-largest chemical company.

Batches of $\mathrm{L}$-tryptophan produced in these months are thus assumed to have contained some chemical impurity that contributes to the development of EMS. Although the researchers do not know what the impurity is, they point out that two changes in procedure took place at Showa Denko around that time. First, the company changed its purification process, reducing by half the amount of carbon used to filter out contaminants. Second, the company introduced a new genetically engineered strain of Bacillus amyloliquefaciens - Strain V - in the fermentation process.

Osterhold and his co-workers are not able to say which of these two factors might have been responsible for the appearance of the postulated impurity. The FDA backs them up, saying that it is impossible to conclude that the use of a "bioengineered organism" was the "key causative factor behind the epidemic".

Showa Denko voluntarily removed its product from the US market in November 1989 when preliminary medical data were released. A company spokesman confirmed that more than 100 law suits have so far been filed against Showa Denko in the United States.

Rifkin has formally requested that the FDA take a "middle course" of action,

which would leave approved drugs and products produced by recombinant-DNA technology on the market but which would suspend the review of all new products until certain measures are completed. The petition calls for a riskassessment study by the FDA of the dangers of recombinant-DNA technology, full public disclosure of its findings so far in the inquiry into the deaths and illnesses associated with L-tryptophan and a re-evaluation of FDA's policy regarding EASTERN EUROPEAN ENVIRONMENT

\section{Munich}

NORWAY has set in motion a plan of unprecedented size and cost to help ease environmental pollution coming from a remote corner of Eastern Europe. Financial aid and loan guarantees are to go from Norway and other Scandinavian countries to the Soviet Union so that it can replace antiquated nickel smelters at Nikel and Zapolyarnyi on the Kola Peninsula, just a few kilometres from the Norwegian border. advocated by some environment analysts who study transboundary pollution, including experts at the International Institute for Applied Systems Analysis (IIASA) in Laxenburg, Austria. Although their advice has so far been ignored, they have said for years that Western Europe would be better off investing its anti-pollution funds directly in Eastern Europe, rather than in trying to ameliorate the effects of pollution in the West.

Acid emissions from the smelters have caused an ecological disaster in Norway's northeasternmost county of Finnmark. The smelters were built in the 1930 s and have operated without pollution controls ever since, dumping nearly 600,000 tonnes of sulphur dioxide a year onto the Soviet Kola Peninsula and neighbouring Norway and Finland.

The sulphur emissions, along with 11,000 tonnes a year of heavy metals, have

\title{
Cleaning Kola with kroner
}

The arrangement is of exactly the type gian Environment Ministry. "Pollution far

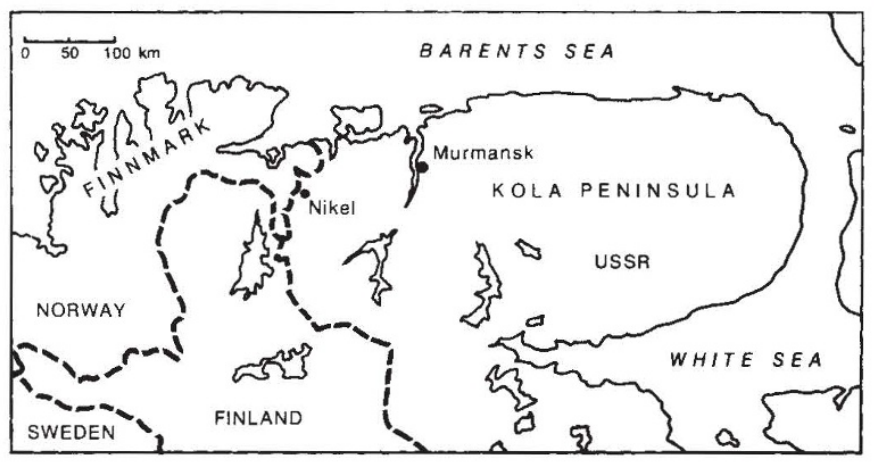
exceeds the critical levels that the environment can absorb." Norwegian officials have also noticed "anomalies" in the incidence of cancer and severe allergic reactions to nickel in Finnmark, but the population of the area is too small for firm conclusions, he says. A study of Soviet

workers at the plants would reveal a significant effect of pollution on health, Antonsen believes.

The Norwegian government expects to complete negotiations for the clean-up in October, says Antonsen. Norway has already promised to pay $\mathrm{NKr} 300$ million (about $\$ 50$ million), and is said to have arranged bank credit of a further $\mathrm{NKr} 700$ million with the Nordic Investment Bank in Helsinki. The Finnish government and perhaps Sweden and Denmark are also expected to participate in the financing.

The overall clean-up will cost much more, perhaps as much as $\mathrm{NKr} 4,000$ million, says Antonsen, of which the Soviets will pay as much as 60 per cent. The Norwegian people stand firmly behind the government in paying for the clean-up, says Antonsen, because they know that reducing Soviet sulphur emissions is the most efficient way to eliminate pollution in Norway.

Steven Dickman 